\title{
Existence of obligately oligotrophic bacteria as a dominant population in the South China Sea and the West Pacific Ocean
}

\author{
Yuzaburo Ishida, Mitsuru Eguchi* \& Hajime Kadota* \\ Department of Fisheries, Faculty of Agriculture, Kyoto University, Kyoto 606, Japan
}

\begin{abstract}
The distribution of obligate oligotrophs in the South China Sea and the West Pacific Ocean was investigated by the ${ }^{14} \mathrm{C}$-MPN method with a medium containing $0.2 \mathrm{mg}$ organic carbon $\mathrm{I}^{-1}$. In surface waters at all stations except Singapore harbour, the total number of heterotrophic bacteria ranged from $1.3 \times 10^{2}$ to $2.5 \times 10^{3}$ cells $\mathrm{ml}^{-1}$, and 45 to $98 \%$ of the total heterotrophs were obligate oligotrophs and the rest facultative oligotrophs. Protein hydrolysate-utilizing oligotrophs and glucoseutilizing oligotrophs were dominant, while acetate-utilizing bacteria were minor components. Bacterial numbers determined by the ${ }^{14} \mathrm{C}$-MPN method were more than an order of magnitude higher than those obtained by the plate count method. The heterotrophic activities $\left(V_{\text {max }}\right)$ of glutamate were remarkably high in the open ocean, while uptake of acetate was undetectable. These results emphasize the importance of obligate oligotrophs in the open ocean.
\end{abstract}

\section{INTRODUCTION}

Aquatic microbiologists have supposed for many years that obligate oligotrophs might exist in nature. We first counted obligate oligotrophs as a dominant population in unpolluted water samples of northern Lake Biwa by using the ${ }^{14} \mathrm{C}-\mathrm{MPN}$ (Most Probable Number) method with a medium containing $0.2 \mathrm{mg}$ organic carbon $\mathrm{l}^{-1}$ (Ishida \& Kadota 1979, Ishida et al. 1980), and we isolated several strains of obligate oligotrophs which grew on low nutrient medium but not on the conventional media such as ZoBell 2216E (Ishida \& Kadota 1981a,b). These findings strongly suggested that particular attention must be paid to nutrient concentrations in media used for counting aquatic bacteria, especially for field work in oligotrophic waters. Since then, we have extended our investigations on the ecology and physiology of obligate oligotrophs to the sea, where the concentration of dissolved organic matter is much lower than in lakes.

The present study shows that obligate oligotrophs are a dominant component of heterotrophic bacteria in

\footnotetext{
- Present address: Department of Fisheries, Faculty of Agriculture, Kinki University, Osaka 577, Japan

the South China Sea and the West Pacific Ocean, where the concentration of utilizable organic substances is lower than in northern Lake Biwa.

\section{MATERIALS AND METHODS}

Sampling area. Water and mud samples were taken during the KH-81-5 cruise of the R/V Hakuho-maru (Ocean Research Institute, University of Tokyo) from October to November 1981. The sampling area is illustrated in Fig. 1. Surface waters were collected using precombusted $\left(450^{\circ} \mathrm{C}, 1 \mathrm{~h}\right) 1000 \mathrm{ml}$ glass bottles which were submerged at $0.5 \mathrm{~m}$ depth, while deeper water samples were taken with sterile Niskin 'butterfly' water samplers. Mud samples were collected with a box-corer. Water samples collected were maintained in precombusted glass bottles in ice and ${ }^{14} \mathrm{C}-\mathrm{MPN}$ and heterotrophic activity were determined within $0.5 \mathrm{~h}$ of sampling.

Enumeration of bacteria. For the enumeration of bacteria by the ${ }^{14} \mathrm{C}-\mathrm{MPN}$ method, 2 types of media, ${ }^{14} \mathrm{C}$-ST $10^{-4}$ and ST $10^{-1}$ media, were used. ${ }^{14} \mathrm{C}$-ST $10^{-4}$ medium contained $0.5 \mathrm{mg}$ trypticase (BBL), $0.05 \mathrm{mg}$ yeast extract (Difco) in $1 \mathrm{l}$ of aged sea water, and 


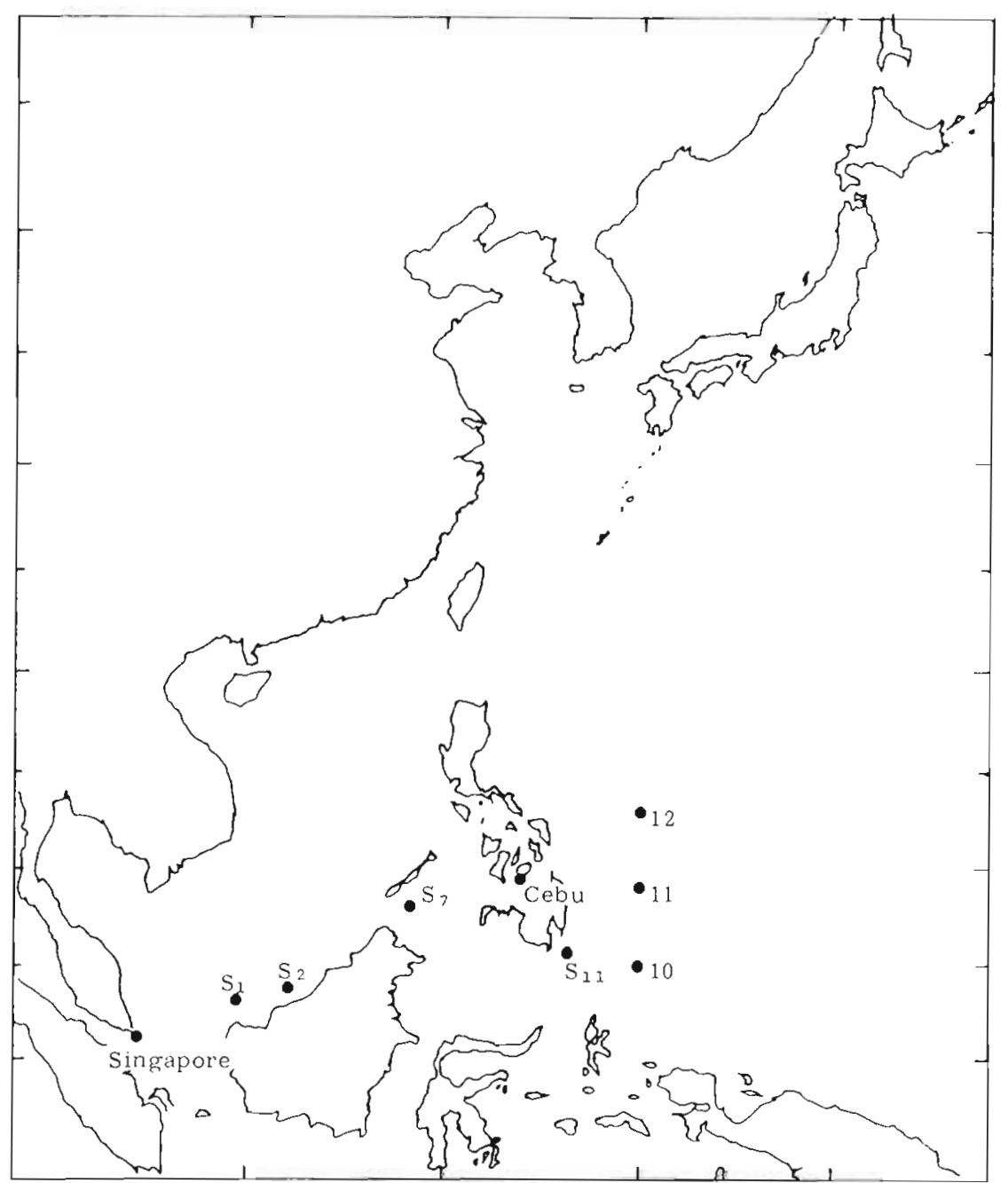

Fig. 1. Sampling area in the South China Sea and West Pacific Ocean

$20 \mathrm{nCi}$ of a ${ }^{14} \mathrm{C}$-organic compound as a tracer level substrate per tube was added to the medium. ST $10^{-1}$ medium contained $0.5 \mathrm{~g}$ trypticase and $0.05 \mathrm{~g}$ yeast extract in 11 of aged seawater. The aged seawater (ASW) was prepared as follows: the seawater was collected from 30 to $50 \mathrm{~m}$ depth in open water, passed through a precombusted Whatman GF/C glass filter and stored in a rinsed glass bottle $(101)$ in the dark at room temperature for more than 1 mo.

Prior to preparation of the 2 kinds of media mentioned above, ASW was passed through a $0.22 \mu \mathrm{m}$ pore size membrane filter (Millipore corp.). To ST10 ${ }^{-4}$ medium, the following ${ }^{14} \mathrm{C}$-organic compounds were added: $\mathrm{L}-\left(\mathrm{U}-{ }^{14} \mathrm{C}\right)$ glutamate $\left(285 \mathrm{mCi} \mathrm{mmol}{ }^{-1}\right),(\mathrm{U}-$ $\left.{ }^{14} \mathrm{C}\right)$ protein hydrolysate $\left(56 \mathrm{mCi}\right.$ milliaton carbon $\left.^{-1}\right)$, D-(U- $\left.{ }^{14} \mathrm{C}\right)$ glucose $\left(268 \mathrm{mCi} \mathrm{mmol}{ }^{-1}\right)$ and $\left(\mathrm{U}-{ }^{14} \mathrm{C}\right)$ acetate $\left(59.6 \mathrm{mCi} \mathrm{mmol}^{-1}\right)$. After inoculation with water samples, the tubes were incubated at $20^{\circ} \mathrm{C}$ for $4 \mathrm{wk}$ as previously described by Ishida et al. (1980), then the most probable number (MPN) for 5 tubes was determined.
Bacterial growth in each tube was detected by turbidity for ST $10^{-1}$ medium and by uptake of ${ }^{14} \mathrm{C}$-compounds for ${ }^{14} \mathrm{C}$-ST $10^{-4}$ medium. In addition to the determination of MPN by ${ }^{14} \mathrm{C}$-uptake, aliquots of a $4 \mathrm{wk}$ old culture of ${ }^{14} \mathrm{C}$-ST10 $10^{-4}$ in each tube were inoculated into freshly prepared ST $10^{-1}$ medium (second medium). Obligate oligotrophs are obtained by subtracting 'counts in the second medium of ST10-1. from ${ }^{14} \mathrm{C}-\mathrm{ST} 10^{-4}$ MPN'. MPN using ${ }^{14} \mathrm{C}-\mathrm{ST} 10^{-4}$ medium $\left({ }^{14} \mathrm{C}-\mathrm{MPN}\right)$ includes both the numbers of obligate oligotrophs and facultative oligotrophs, and MPN using ST10 ${ }^{-1}$ medium (turbidity MPN; T-MPN) includes both facultative oligotrophs and eutrophs. We previously defined obligate oligotrophs as organisms which grow in ${ }^{14} \mathrm{C}$-ST $10^{-4}$ medium and are unable to grow in ST10 $0^{-1}$ medium (second medium), and eutrophs as organisms which grow in ST10-1 medium and are unable to grow in ${ }^{14} \mathrm{C}$-ST $10^{-4}$ medium (Ishida et al. 1980). The total number of heterotrophs is the sum of the number of obligate oligotrophs, facultative oligotrophs and eutrophs. 
Turbidity (NTU; Nephelometric Turbidity Units) of surface water was measured with a DRT-15 turbidmeter (HF Instruments, Canada).

In situ heterotrophic activity. The technique used in this study was basically as described by Wright \& Hobbie (1966). A series of $0.05,0.10,0.15,0.20$ and $0.25 \mu \mathrm{M}$ solutions of L-glutamate or acetate with 10,20 , 30,40 , and $50 \mathrm{nCi}$ of ${ }^{14} \mathrm{C}$-glutamate or ${ }^{14} \mathrm{C}$-acetate (final volume; $35,70,105,140$ and $175 \mu \mathrm{l}$, respectively) were prepared in screw-cap test tubes. Duplicate sets of $5 \mathrm{ml}$ seawater samples were poured into each tube. The final concentrations of glutamate were 0.057 , $0.112,0.167,0.222$ and $0.275 \mu \mathrm{M}$, and those of acetate were $0.083,0.167,0.274,0.327$ and $0.406 \mu \mathrm{M}$. Water samples were incubated for 1 to $6 \mathrm{~h}$ in the dark within 1 to $2 \mathrm{C}^{\circ}$ of the in situ temperature. After incubation, sample were filtered through 0.22 um membrane filters (Millipore corp.), and washed with $10 \mathrm{ml}$ of filtered seawater 3 times. For the blank, one sample was filtered immediately after the addition of the water samples in each tube. The filters were dried under IR lamps and placed in scintillation vials containing $10 \mathrm{ml}$ of toluene fluor. Then their radioactivity was determined with a liquid scintillation counter (Aloka
LSC 502). Parameters of maximum uptake velocity $\left(V_{\max }\right)$, the saturation constant plus the substrate concentration in nature $\left(K_{1}+S_{n}\right)$ and the apparent turnover time for the natural substrate $\left(T_{\text {l) }}\right)$ were calculated using the modified Lineweaver-Burg equation.

\section{RESULTS}

\section{Distribution of oligotrophic bacteria}

The horizontal distribution of the bacterial population was determined by the use of ${ }^{14} \mathrm{C}-\mathrm{MPN}$ and colony counts as shown in Fig. 2. The ${ }^{14} \mathrm{C}-\mathrm{MPN}$ values were expressed as the highest value obtained with the 4 different kinds of ${ }^{14} \mathrm{C}$-labeled compounds. The ${ }^{14} \mathrm{C}-\mathrm{MPN}$ in surface water at each station in the West Pacific Ocean (Stns $S_{11}, 10,11 \& 12$ ) gave values one order of magnitude lower ( 2 to $7 \times 10^{2} \mathrm{ml}^{-1}$ ) than those in the South China Sea (Stns $S_{1}$ and $S_{2}$ ), the Sule Sea (Stn $S_{7}$ ) and Bohol Strait near Cebu (Stn Cebu). At the station $1.5 \mathrm{~km}$ offshore from Singapore harbour the ${ }^{14} \mathrm{C}-\mathrm{MPN}$ value was as high as $2.2 \times 10^{5} \mathrm{ml}^{-1}$. The horizontal profile of ${ }^{14} \mathrm{C}$-MPN values were positively correlated to

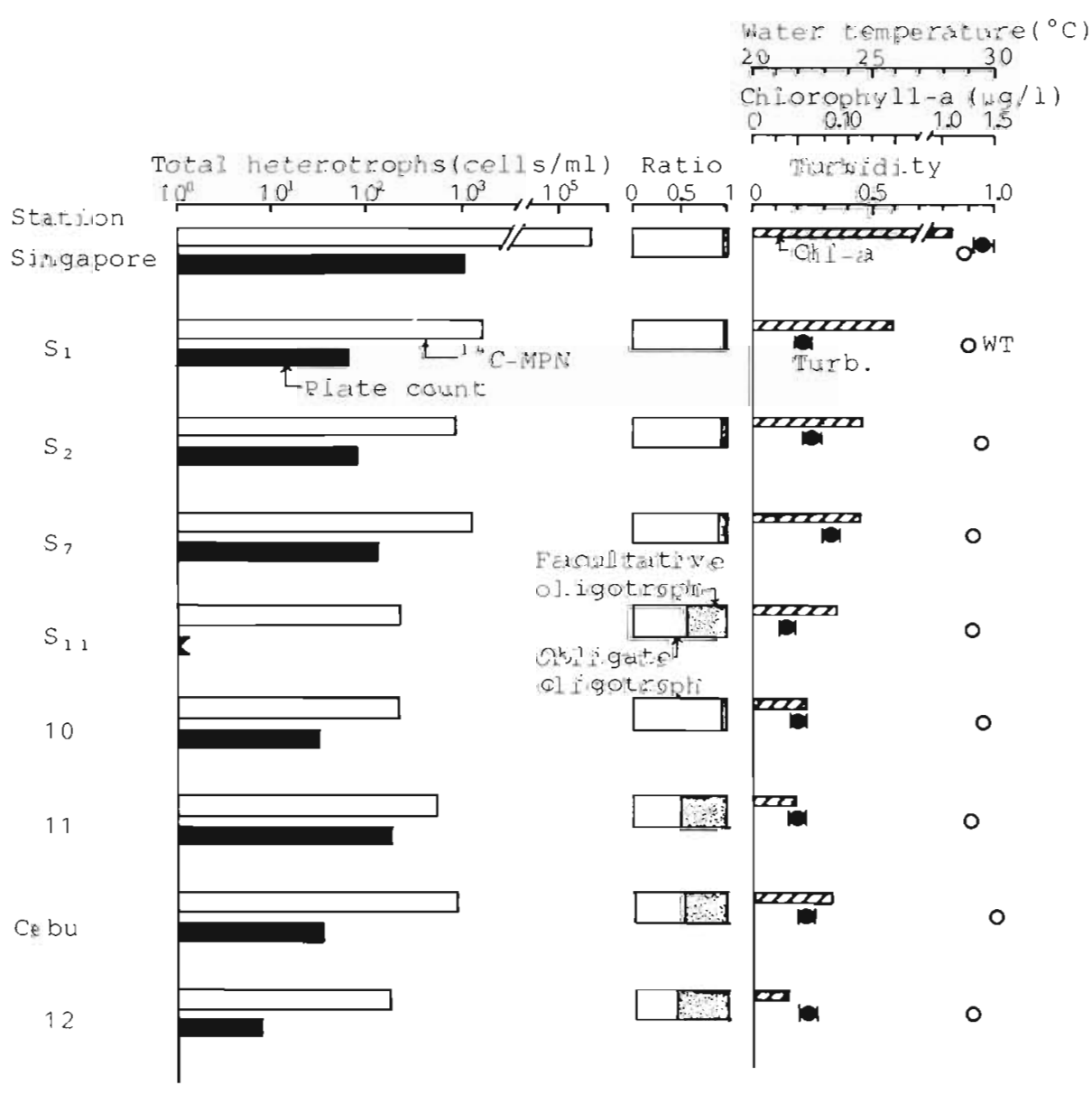

Fig. 2. Horizontal distribution of total heterotrophs and ratio of obligate and facultative oligotrophs to total heterotrophs 
those of both chlorophyll-a content $\left(r^{2}=0.72\right)$ and the turbidity of the seawater. In this experiment ${ }^{14} \mathrm{C}-\mathrm{MPN}$ values were remarkably higher than MPN values with ST $10^{-1}$ media (T-MPN) and colony counts with ST10 $0^{-1}$ media, and no eutrophic bacteria were detected in surface waters at any of the stations. Therefore, the ${ }^{14} \mathrm{C}$-MPN values which show the total number of oligotrophs approximately correspond to the total number of heterotrophs at those stations. The ratio of obligate oligotrophs to total heterotrophs ranged from 45 to $98 \%$. The remainder were facultative oligotrophs. The ratio of total heterotrophs to total bacterial number (direct count) ranged from 0.02 to $0.08 \%$ at Stns 10,11 and 12 .

The vertical distribution of the bacterial population, chlorophyll-a, water temperature and turbidity at Stns 11 and 12 are illustrated in Fig. 3. At both stations, the numbers of total heterotrophs in surface waters were high $\left(7.0 \times 10^{2}\right.$ and $\left.1.8 \times 10^{2} \mathrm{ml}^{-1}\right)$ and decreased roughly exponentially with depth although a chlorophyll-a maximum layer was located at $75 \mathrm{~m}$ depth at Stn 11 and at $125 \mathrm{~m}$ depth at Stn 12.

In the surface waters at both stations and at $125 \mathrm{~m}$ at Stn 11 most heterotrophs were facultative and obligate oligotrophs, whereas at $400 \mathrm{~m}$ depth at both stations and at $150 \mathrm{~m}$ depth at Stn 12, high percentages of eutrophic bacteria (20 to $63 \%$ ) were obtained in addition to both types of oligotrophs (Fig. 3). The reason why eutrophic bacteria were comparatively abundant at $150 \mathrm{~m}$ and $400 \mathrm{~m}$ remains unknown.

At the surface of the sediments, the population densities of heterotrophs were $7.2 \times 10^{2} \mathrm{ml}^{-1}$ at Stn 11 and $1.7 \times 10^{2} \mathrm{ml}^{-1}$ at Stn 12 . As much as $70 \%$ of these populations consisted of obligate oligotrophs and there were no eutrophic bacteria.

The number of heterotrophic bacteria (mainly oligo-

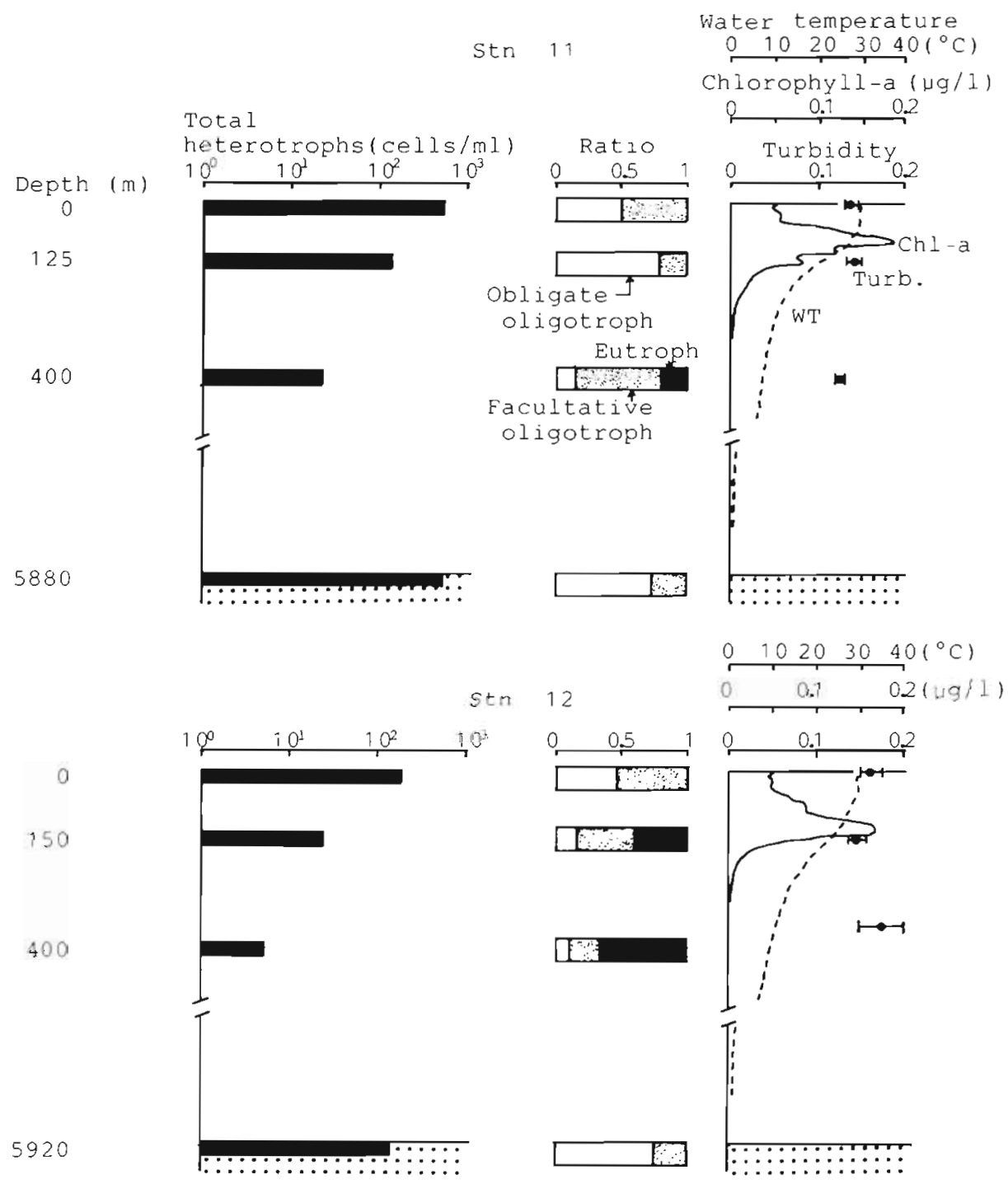

Fig. 3. Vertical distribution of total heterotrophs counted by the ${ }^{14} \mathrm{C}$-MPN method at Stn 11 and Stn 12 
Fig. 4. The number and the ratio of oligotrophic bacteria utilizing acetate, glucose, glutamate and protein hydrolysate

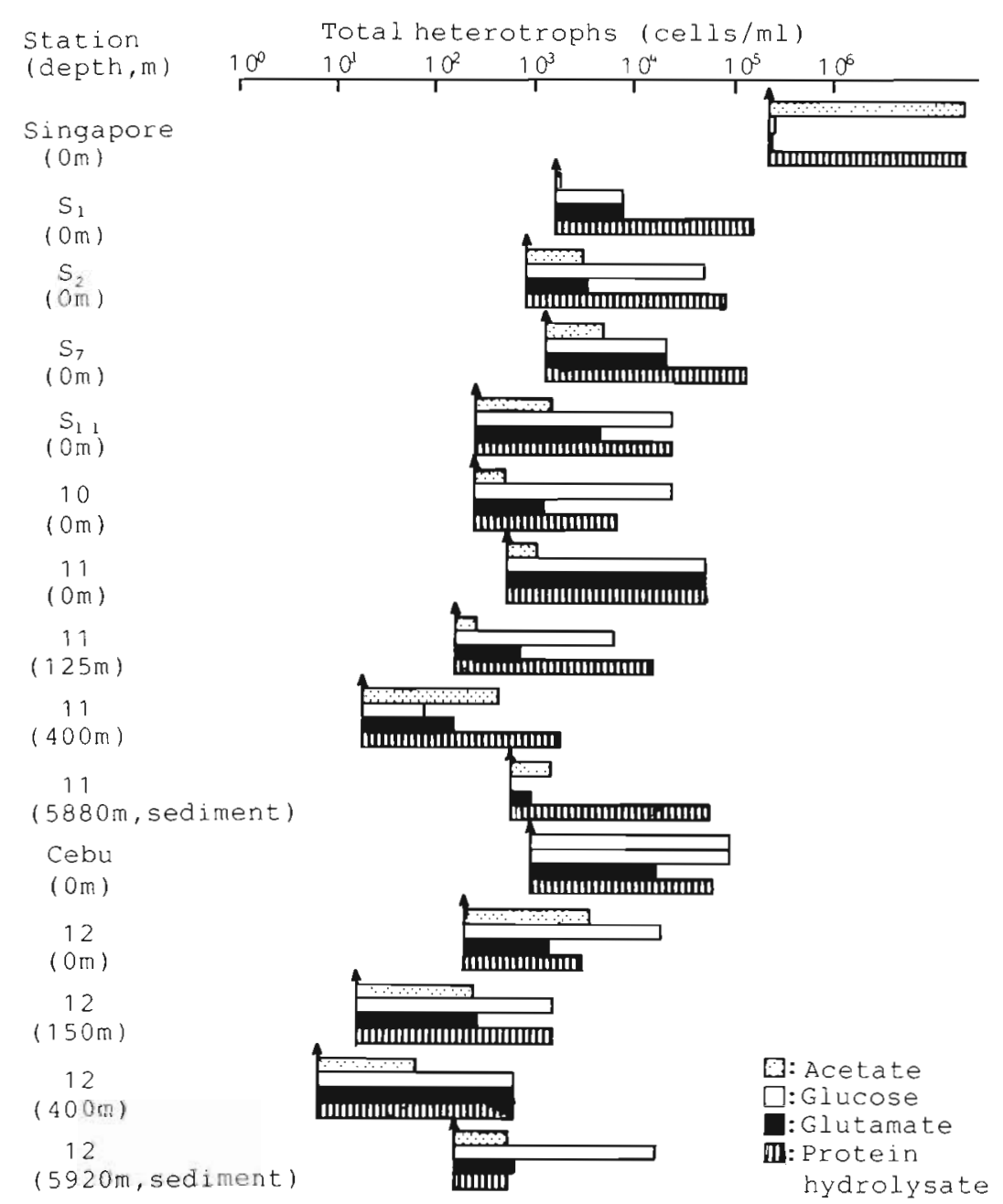

trophs) was counted using the ${ }^{14} \mathrm{C}-\mathrm{MPN}$ method with each of the $4{ }^{14} \mathrm{C}$-labelled compounds as a tracer. Fig. 4 shows the compound most effectively utilized by the dominant oligotrophs at each station. There was a tendency for protein hydrolysate-utilizing oligotrophs to be predominant in surface waters in the South China Sea (Stns $S_{1}$ and $S_{2}$ ) and the Sule Sea $\left(\operatorname{Stn} S_{7}\right)$, while in the West Pacific Ocean (Stns $S_{11}, 10,11$ and 12) and Bohol Strait (Stn Cebu), glucose-utilizing oligatrophs were dominant. Acetate-utilizing oligotrophs, however, were minor in the surface waters at all unpolluted stations except Singapore harbour and Bohol Strait.

\section{In situ heterotrophic activity}

Heterotrophic activities of water samples were examined by use of 2 substrates (glutamate and acetate). The values of the 3 parameters of heterotrophic potential $\left(\mathrm{V}_{\max }\right)$, turnover time $\left(\mathrm{T}_{\mathrm{t}}\right)$ and $\left(\mathrm{K}_{\mathrm{t}}+\mathrm{S}_{\mathrm{n}}\right)$ for each sample are shown in Table $1 . V_{\max }$ in the surface waters of Singapore harbour was 1 order of magnitude higher than at the other stations, while $T_{t}$ was 1 order of magnitude lower. A good correlation was observed between the uptake parameters $\left(V_{\max }\right.$ and $\left.T_{t}\right)$ of glutamate and the densities of total oligotrophic bacteria as determined by ${ }^{14} \mathrm{C}-\mathrm{ST} 10^{-4}-\mathrm{MPN}$. The uptake of acetate, however, was undetectable in all samples except one at Singapore harbour at a substrate concentration range of 0.083 to $0.406 \mu \mathrm{M}$. This was the case even at Bohol Strait (Stn Cebu), where the density of acetateutilizing bacteria was higher than that of glutamateutilizing bacteria. Though the number of glutamateutilizing bacteria was not as high as that of acetateutilizing bacteria in the water samples of polluted Singapore harbour, the $T_{t}$ of glutamate uptake was 1 order of magnitude lower than that of acetate.

The chlorophyll-a and water temperature data were cited from preliminary data report of the KH-81-5 cruise of the R/V Hakuho-maru. 
Table 1. Kinetic parameters for the uptakes of glutamate and acetate by heterotrophs in the natural environment

\begin{tabular}{|cccc|}
\hline $\begin{array}{c}\text { Station } \\
(\text { Depth, })\end{array}$ & $\begin{array}{c}\mathrm{V}_{\max } \\
\left(\mu \mathrm{M} \mathrm{h}^{-1}\right)\end{array}$ & $\begin{array}{c}\text { Turnover } \\
\text { time }(\mathrm{h})\end{array}$ & $\begin{array}{c}\mathrm{K}_{\mathrm{t}}+\mathrm{S}_{\mathrm{n}} \\
(\mu \mathrm{M})\end{array}$ \\
\hline $\begin{array}{c}\text { Singapore } \\
(0 \mathrm{~m})\end{array}$ & A $3.8 \times 10^{-3}$ & 43.2 & 0.16 \\
$\mathrm{~S}_{1}$ & B $2.0 \times 10^{-3}$ & 642.9 & 1.26 \\
$(0 \mathrm{~m})$ & A $2.5 \times 10^{-4}$ & 614.1 & 0.16 \\
$\mathrm{~S}_{2}$ & B $\mathrm{NMA}$ & - & - \\
$(0 \mathrm{~m})$ & A $5.0 \times 10^{-4}$ & 672.2 & 0.39 \\
10 & B NMA & - & - \\
$(0 \mathrm{~m})$ & A $2.7 \times 10^{-4}$ & 541.7 & 0.15 \\
11 & B NMA & - & - \\
$(0 \mathrm{~m})$ & A $1.6 \times 10^{-4}$ & 563.6 & 0.09 \\
11 & B NMA & - & - \\
$(125 \mathrm{~m})$ & A $8.9 \times 10^{-5}$ & 1117.5 & 0.10 \\
Cebu & B NMA & - & - \\
$(0 \mathrm{~m})$ & A $3.3 \times 10^{-4}$ & 402.6 & 0.13 \\
12 & B NMA & - & - \\
$(0 \mathrm{~m})$ & A $1.0 \times 10^{-4}$ & 1224.5 & 0.13 \\
12 & B NMA & - & - \\
$(150 \mathrm{~m})$ & A $2.8 \times 10^{-5}$ & 11466.0 & 0.32 \\
A $\mathrm{NMA}$ & - & - \\
glutamate; B: acetate; NMA: no measurable activity & \\
\hline
\end{tabular}

\section{DISCUSSION}

In surface waters of the oligotrophic open ocean, such as the South China Sea and the West Pacific Ocean, the population density of total heterotrophic bacteria estimated by use of the ${ }^{14} \mathrm{C}-\mathrm{MPN}$ method ranged from $1.3 \times 10^{2}$ to $2.5 \times 10^{3} \mathrm{ml}^{-1}$ (average $9.1 \times 10^{2} \mathrm{ml}^{-1}$ ), and 45 to $98 \%$ of total heterotrophs were obligate oligotrophs. This type of oligotroph cannot be detected by the Turbidity-MPN (T-MPN) or colony count method with conventional media (such as ZoBell 2216E). The population densities presented in this paper using the ${ }^{14} \mathrm{C}$-MPN method are more than 1 order of magnitude higher than those reported previously in, for example, the Nansei Shoto Area (Akagi et al. 1977, Simidu et al. 1980) and the Cook Inlet, Alaska (Horowitz et al. 1983). In these studies, the total heterotrophs were counted by the plate-counting method using conventional media. From the results of the present study using ${ }^{14} \mathrm{C}$-compounds in the low nutrient media, it is clear that obligate oligotrophs prefer amino acids to acetate and the range of substrates they can utilize is relatively narrow. The percentage of obligate oligotrophs among the total heterotrophs in these oceanic waters is significantly higher than in Lake Biwa (Ishida et al. 1980). These findings may be related to the low concentrations of free amino acids in seawater of about 58 to $120 \mathrm{nmol} \mathrm{l}^{-1}$ (Andrews
\& Williams 1971, Lee \& Bada 1975, Eguchi \& Ishida unpubl.). Glycine and serine are generally most abundant in the open ocean, followed by alanine, aspartic acids and glutamic acids.

The maximum uptake velocities $\left(V_{\max }\right)$ of glutamate were remarkably high in the open ocean, while the uptakes of acetate were undetectable. Many attempts to measure heterotrophic activity in extremely oligotrophic waters have failed to get the usual kinetic response (e.g. Vaccaro \& Jannasch 1966), because they usually used glucose or acetate but not amino acids as a substrate (Eguchi \& Ishida unpubl.). In Antarctic waters also, acetate uptake was very low in all cases and often undetectable (Gillespie et al. 1976, Eguchi \& Ishida unpubl.). It seems that the obligate oligotrophs present in this study had a high specificity for substrates as in the case of northern Lake Biwa (Ishida \& Kadota 1981a).

According to Lee \& Bada (1975), the amount of combined amino acids present was about 10 times more than that of free amino acids in the open ocean, and serine, alanine and probably glycine were the major components among both combined and free amino acids in surface and deeper waters. Free amino acids such as glycine, serine and glutamic acids are favorable substrates for oligotrophic bacteria (Ishida \& Kadota 1981a). The combined amino acids are assumed to be taken up by bacteria after being dehy-

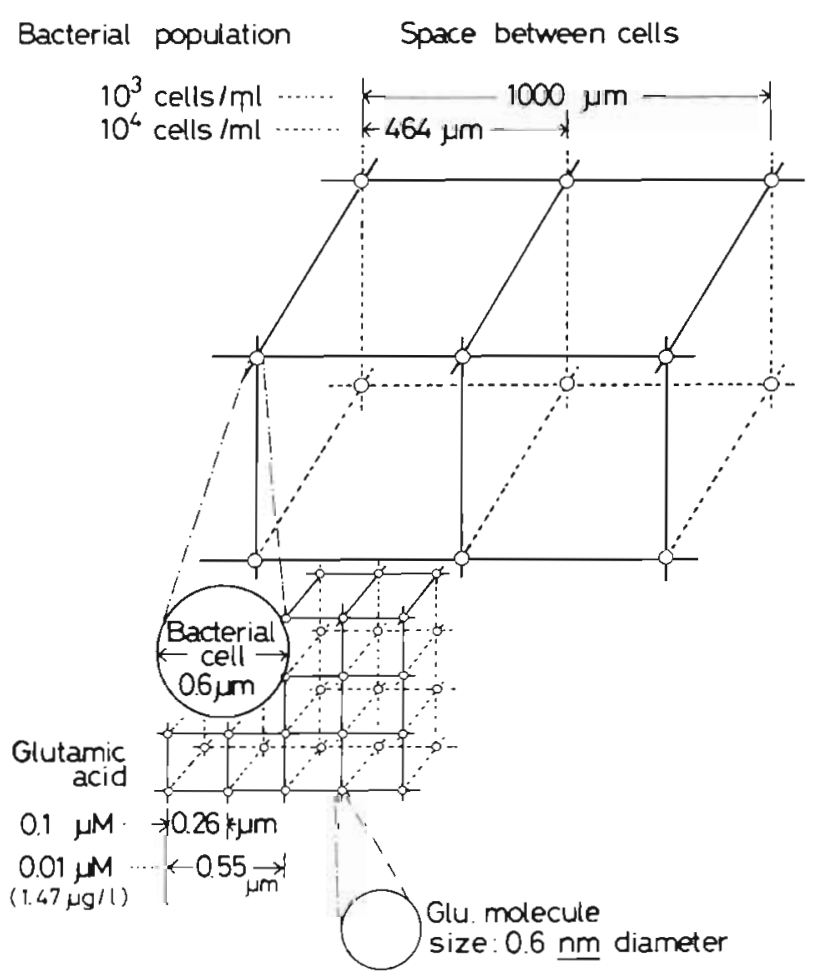

Fig. 5. Model of the spatial relation between bacterial particles and glutamate molecules in the open ocean 
drolised to free amino acids or oligopeptides. It is therefore probable that free amino acids are continuously supplied from combined amino acids, even if the amount of free amino acids is very small in deep water.

As shown is Fig. 5, the distance between cells can be calculated roughly to be $1000 \mu \mathrm{m}$ when a bacterial population density of $10^{3}$ cells $\mathrm{ml}^{-1}$ is distributed homogenously in the open ocean, while the distance between molecules of glutamate would be $0.55 \mu \mathrm{m}$ which approximately corresponds to the mean diameter of bacterial cells when the concentration of glutamate is $10 \mathrm{nM}\left(1.5 \mu \mathrm{g} \mathrm{l}^{-1}\right)$. This calculation shows that a single cell of bacteria constantly has the chance to meet 8 molecules of glutamate. According to Einstein's equations on Brownian movement (Einstein 1956), we obtain $22.6 \mu \mathrm{m} \mathrm{s}^{-1}$ as the velocity of a glutamate molecule. If bacterial movement $\left(0.8 \mu \mathrm{m} \mathrm{s}^{-1}\right)$ is neglected, a rough estimate of the number of collisions of molecules with bacterial cells is more than $1 \times 10^{6} \mathrm{~s}^{-1}$. This collision value must increase greatly if flagella movement and chemotactic behaviour are also considered. In the open ocean, marine bacteria may have significant chances of meeting amino acids molecules which they can use for their growth (Ishida et al. 1982).

Martin \& MacLeod (1984) expressed grave doubts about the existence of 2 broad classes of bacteria (eutrophic bacteria and oligotrophic bacteria) on the basis of growth at $10 \mathrm{mg} \mathrm{Cl}^{-1}$ using bacteria provided by Akagi, Japan. Our results using the ${ }^{14} \mathrm{C}-\mathrm{MPN}$ method suggest that their 2 types of bacteria isolated by using a specific filter method are not a major component of living marine bacteria.

Acknowledgements. We thank the scientists, captain, officers and crew of the R/V Hakuho-maru, University of Tokyo for their kind assistance in sampling during the KH-81-5 cruise, and also Dr. A. Kawai, Department of Fisheries, Faculty of Agriculture, Kinki University, for helpful comments on this manuscript. This study was partly supported by funds granted by the Ministry of Education, Japan (Grant Nos 511916. 56115017, 57108016).

\section{LITERATURE CITED}

Akagi, Y., Taga, N., Simidu, U. (1977). Isolation and distribution of oligotrophic marine bacteria. Can. J. Microbiol. 23 981-987

Andrews, P., Williams, P. J. leB. (1971). Heterotrophic utilization of dissolved organic compounds in the sea. III. Measurement of the oxidation rates and concentrations of glucose and amino acids in sea water. J. mar biol. Ass. U. K. $51 \cdot 111-125$

Einstein, A. E. (1956). Investigations on the theory of the Brownian movement. Dover Publication Inc., New York

Gillespie, P. A., Morita, R. Y., Jones, L. P. (1976). The heterotrophic activity for amino acids, glucose and acetate in Antarctic waters. J. oceanogr. Soc. Japan 32: 74-82

Horowitz, A., Krichevsky, M. I., Atlas, R. M. (1983). Characteristics and diversity of subarctic marine oligotrophic, stenoheterotrophic and euryheterotrophic bacterial populations. Can. J. Microbiol. 29: 527-535

Ishida, Y., Kadota, H. (1979). A new method for enumeration of oligotrophic bacteria in lake water. Arch. Hydrobiol Beih. Ergeb. Limnol. 12: 77-85

Ishida, Y., Shibahara, K., Uchida, H., Kadota, H. (1980). Distribution of obligately oligotrophic bacteria in Lake Biwa. Bull. Jap. Soc. scient. Fish. 46: 1151-1158

Ishida, Y., Kadota, H. (1981a). Growth patterns and substrate requirements of naturally occurring obligate oligotrophs. Microb. Ecol. 7: 123-130

Ishida, Y., Kadota, H. (1981b). Obligately oligotrophic bacteria in Lake Biwa. Verh. int. Verein. Limnol. 21 552-555

Ishida, Y., Imai, I., Miyagaki, T., Kadota, H. (1982). Growth and uptake kinetics of a facultatively oligotrophic bacterium at low nutrient concentrations. Microb. Ecol. 8: 23-32

Lee, C., Bada, J. L. (1975). Amino acids in equatorial Pacific Ocean water. Earth. Planet. Sci. Lett. 26: 61-68

Martin, P., MacLeod, R. A. (1984). Observations on the distinction between oligotrophic and eutrophic marine bacteria. Appl. environ. Microbiol. 47: 1017-1022

Simidu, U., Taga, N., Colwell, R. R., Schwarz, J. R. (1980). Heterotrophic bacterial flora of the seawater from the Nansei Shoto (Ryukyu Retto) Area. Bull. Jap. Soc. scient. Fish. 46: 505-510

Vaccaro, R. F., Jannasch, H. W. (1967). Variations in uptake kinetics for glucose by natural populations in seawater. Limnol. Oceanogr. 12: 540-542

Wright, R. T., Hobbie, J. E. (1966). Use of glucose and acetate by bacteria and algae in aquatic ecosystems. Ecology 47 : $447-468$ 